\title{
The Queer Politics of Migration: Reflections on "Illegality" and Incorrigibility
}

\author{
NICHOLAS DE GENOVA ${ }^{1}$ \\ Center for the Study of Race, Politics, and Culture, University of Chicago
}

\begin{abstract}
The most resounding expression of the truly unprecedented mobilizations of migrants throughout the United States in 2006 was a mass proclamation of collective defiance: ¡Aquí Estamos, y No Nos Vamos! [Here we are, and we're not leaving!]. This same slogan was commonly accompanied by a still more forcefully incorrigible rejoinder: ¡Y Si Nos Sacan, Nos Regresamos! [... and if they throw us out, we'll come right back!]. It is quite striking and, as this essay contends, not merely provocative but genuinely productive to note the affinity between the crucial articulation of this radically open-ended politics of migrant presence with the similarly abject and profoundly destabilizing politics of queer presence. In a manner remarkably analogous to the slogan, "We're here, we're queer, get used to it!", the dynamic enunciation of these phrases in the context of the mass mobilizations of migrants asserted an irreducible spirit of irreverence and disaffection for state power. Both gestures unreservedly and unapologetically assert not only their irreversible presence, furthermore, but also uphold the intractable challenge of their own intrinsic incorrigibility.
\end{abstract}

¡Aquí Estamos, y No Nos Vamos! [Here we are, and we're not leaving!].

—Migrant mobilization slogan

We're Here, We're Queer, Get Used to It!

-Queer mobilization slogan

"This is an anti-assimilationist narrative about an anti-assimilationist movement."

—Lauren Berlant and Elizabeth Freeman, "Queer Nationality” (1992, p. 154)

The most resounding-and indeed, for me, the most resplendent-expression of the truly unprecedented mobilizations of migrants throughout the United States in 2006 was a mass proclamation of collective defiance: ¡Aquí Estamos, y No Nos Vamos! [Here we are, and we're not leaving!]. This same slogan was commonly accompanied by a still more forcefully incorrigible rejoinder: ¡Y Si Nos Sacan, Nos Regresamos! [... and if they throw us out, we'll come right back!]. The chant itself was not new; it has been a potent and enduring articulation of migrant struggles in the United States for many years. ${ }^{2}$ But the dynamic enunciation of these phrases in

Correspondence Address: Nicholas De Genova, Center for the Study of Race, Politics, and Culture; University of Chicago, 5733 S. University Ave. Chicago, IL 60637 USA. Tel: +1 773 702-8063; Email: n.degenova@gmail.com 
the context of the mass mobilizations reinvigorated their irreducible spirit of irreverence and disaffection for state power.

It is well-known, and needs no rehearsing here, that the 2006 mobilizations were instigated by the passage in the U.S. House of Representatives of the now-infamous Border Protection, Antiterrorism and Illegal Immigration Control Act (HR4437, passed on December 16, 2005, also known as the Sensenbrenner bill), which would unquestionably have been the most punitive immigration legislation in U.S. history. This particularly repressive attempted legislative ambush explicitly conjoined its proposed criminalization of "illegal immigration" with the dominant metaphysics of antiterrorism, and overtly signalled its own condition of possibility under the aegis of what I have designated the Homeland Security State (De Genova, 2007a). In response, millions of migrants ("illegal" and "legal" alike), along with their often U.S.-citizen children, rallied and marched in protests across the United States, taking the country by storm repeatedly over a period of nearly two months (Baker-Cristales, 2009; Bloemraad \& Trost, 2008; De Genova, 2009; Gonzales, 2009; Heiskanen, 2009; Hincapié, 2009; Johnson and Hing, 2007; Pulido, 2007; Robinson, 2006; Lazos Vargas, 2007; Voss \& Bloemraad, n.d.). ${ }^{3}$ An utterly unforeseen insurgency ${ }^{4}$ of overwhelmingly working-class (or working poor), racially subordinate (non-white), and often legally vulnerable (deportable) people created a political crisis for the U.S. state-destabilizing the antiterrorist complacencies and nativist commonsense of the dominant discourse, disorienting and paralyzing the political establishment's official "immigration reform" debate, and finally de-railing the proposed law. Indeed, in this regard, one need not quibble about whether these mobilizations truly constituted a "movement," as such, or merely a kind of "event" which seemed to evaporate as abruptly as it had appeared: unlike many other more prolonged and entrenched social or political movements, this one actually exerted so much force that it very quickly achieved its premier and defining goal-it summarily defeated the menacing and abhorrent legislation. The sovereign power of the national state and its asphyxiating politics of citizenship were abruptly short-circuited by the abject agency of global capital's transnational denizens (De Genova, 2009; cf. 2010b).

It is not the claim of this essay that the politics of the 2006 mobilizations in the United States were in any sense a "pure" or "pristine" outburst of counter-hegemonic energies and radical critique-uncontaminated, as it were, by the hegemonic assimilationist compulsions and nationalist conceits of dominant U.S. immigration discourse (De Genova, 2005, pp. 56-94). On the contrary, what is at stake in this essay is precisely to deepen and clarify the critique of those epistemological and methodological dilemmas and political conundrums. Nor is it the pretence of this essay to superimpose any semblance of ready-made dogmatic coherence upon a mass movement which was plainly heterogeneous and riddled with its own contradictions. Such efforts would seem to be fanciful in the extreme, naively romanticizing a sociopolitical field that deserves rather more sober and exacting scrutiny. But the tremendous extent to which the "aquí estamos" chant has been acknowledged as the preeminent crystallization of a persistent and urgent collective sensibility of the protests is undeniable and noteworthy (see, e.g., Hincapié, 2009; Robinson, 2006). Inasmuch as this slogan, arguably more than any other, evidently had a profound resonance on an immense scale for migrants engaged in this struggle, it is imperative that we take its substance to be an organic expression of one of the determinate 
impulses-which, of course, is not to say the only one-that animated the mobilizations and energized their political imagination.

Thus, if the movement had a clear and concise immediate task (the defeat of HR4437), which it achieved with stunning rapidity, it also articulated itself in a variety of broader terms. Here we are, and we're not leaving! So rang out the movement's most elementary message, its most elemental expression of political prerogative. Notably, this was not a "demand": it petitioned no legislators, pleaded no legal case, pandered to no politicians, deferred to no law enforcement authorities. Instead, this recurrent chant exuberantly affirmed the theme of presence-the profound and inextricable presence of migrants, and especially that of the undocumented, within the U.S. social formation and within the space of the state. Indeed, the question of migrants' "unlawful presence" (precisely the target objectified for criminalization by the proposed law) signalled a crucial flashpoint for both sides in the political struggle over immigration in the United States. As will be seen, this assertion of migrant presence as a "political" fact, enunciated in relation to the state, was simultaneously and inseparably an "economic" fact based upon the inextricable presence of the (labour-)power of migrants, as workers. For many of the migrants who thus engaged in the so-called "immigration debate" through their participation in these mass mobilizations, their "unauthorized" presence ultimately figured as the definitive social and political "objective" fact: its audacious affirmation-its reinscription as sheer insubordination-seemed to signify an end in itself (De Genova, 2009).

The bold and fearless character of this posture, furthermore, was only surpassed by its uncompromising intransigence and incorrigibility: this was a profoundly antiassimilationist gesture. We are here, they proclaimed, and by implication, they insisted: We are who we are, and what we are. The millions who literally put their deportable bodies on the line in this struggle - at least, when they chanted this slogan —were not begging anyone for their putative civil or human "rights," were not asking any authorities for permission or pardon, and did not seek anyone's approval or acceptance. $^{5}$ Through the insolent promise that even in spite of deportation, they would inexorably return, moreover, these migrants likewise taunted the smug and sanctimonious superintendents of the deportation regime: There's nothing you can do about it-your repressive power is nothing compared to the power of our vitality and our indomitable will to persevere and prevail.

It is quite striking and, as I contend in this essay, not merely provocative but genuinely productive to note the affinity between the crucial articulation of this radically open-ended politics of migrant presence with the similarly abject and profoundly destabilizing politics of queer presence. ${ }^{6}$ The two slogans, juxtaposed as epigraphs to this essay, in effect, make exactly the same declaration: We are here, we refuse to leave, and we cannot be excised. In a manner remarkably analogous to the slogan, "We're here, we're queer, get used to it"-originally associated with the militants of Queer Nation ${ }^{7}$ (especially gay men with AIDS and their allies) - the "aquí estamos" chant of the migrant mobilizations "stages the shift from silent absence into present speech, from nothingness to collectivity, from a politics of embodiment to one of space, whose power erupts from the ambiguity of 'here'” (Berlant \& Freeman, 1992, p. 156). Both gestures unreservedly and unapologetically assert not only their irreversible presence, therefore, but also uphold the intractable challenge of their own intrinsic incorrigibility. 


\section{Migrant Abjection / Queer Politics}

As the objects of an unprecedented and escalating climate of securitization, migrants have been increasingly depicted over the last several years as possessing a dubious agency that is unsavoury at best, if not plainly dangerous (De Genova, 2007a). Abjection is an especially apt interpretive frame through which to appreciate the complexities of the migrant condition, precisely because migrants are always-already within the space of the state and can never really be entirely expelled. Julia Kristeva has memorably depicted the specificity of the concept of the abject as "something rejected from which one does not part." Although she depicts it in terms of "the jettisoned object," the abject is not in fact a properly external object. It becomes difficult to fully differentiate the self from the abject which it seeks to expunge. Thus, because it cannot ever be truly extricated, the abject "from its place of banishment ... does not cease challenging its master," and its ostensible "exclusion" only draws the subject "toward the place where meaning collapses." The distinctly disruptive force of the abject involves that which "disturbs identity, system, order. What does not respect borders, positions, rules. The in-between, the ambiguous, the composite” (1980/1982, pp. 1-4; cf. Chow 2001; De Genova 2008). The political mobilization of migrants in 2006 entailed the sort of abject irruption to which Kristeva refers-exposing an abject subjectivity that, as Peter Nyers (2003) has insightfully suggested, presents "a troubling anomaly to the sovereign order" (p. 1090). By articulating political demands and making claims, and thereby producing or reconfiguring the spaces of the political (pp. 1070-1071), migrant protesters moved "the question of the speaking subject front and centre" to "provoke fundamental questions about politics [and] ... who can be political” (p. 1089). Such critical ruptures confront (and affront) political regimes premised upon the supposed "impossibility" that officially rightless non-citizens could assume the mantle of quasi-citizenship, authorizing themselves to speak, reconfiguring the space of the public, and making claims of entitlement (McNevin, 2006, 2009; Varsanyi, 2006).

We have been witnessing an unprecedented proliferation of these sorts of new, asyet "unnamed," and fundamentally "inarticulable" figures of political agency. As Engin Isin (2009) suggests, these figures may be variously described as "migrants," "refugees," "foreigners," etc., but they fundamentally resist categorization because they unsettle the very attempt to fix that agency within such given categories, and in so doing, also unsettle the very premises of citizenship (pp. 367-68). Isin seeks to discern "a new vocabulary of citizenship" in these figures of "activist citizenship" and the corresponding "emergence of new 'sites', 'scales' and 'acts' through which 'actors' claim to transform themselves (and others) from subjects into citizens as claimants of rights" (pp. 368). By emphasizing the constituent character of "citizenship understood as political subjectivity" and "acts of citizenship" as the acts by which such subjects make themselves (pp. 383; cf. Isin, 2008), Isin posits a notion of citizenship which is always incipient, a kind of citizenship-to-come, which might serve indeed to describe some of the stakes of the migrant activism with which I am concerned. Yet, it is equally crucial to recognize, at least in the potent example of these "illegal" migrants' mobilizations in 2006, that this particular explosion of activist energies was unapologetically premised nonetheless upon the hard juridical fact of these migrants' statutory non-citizenship and the consequent social fact of their more general abjection within the spaces of "the political" as sanctioned by the 
state. There was, in short, a question of politics at stake in the 2006 movement which exceeded the purview of the political as designated by the U.S. state. The putatively "national" territory of the United States was transposed into a mere site where the global social relation of labour and capital revealed its inherently transnational spatial scale and scope. Although the U.S. state's regime of migrant "illegality" was the immediate referent and supplied the material and practical occasion for the struggle, this was a politics that extravagantly parochialized the U.S. "national" state as such. By destabilizing the "national" space of the U.S. state's jurisdiction and coaxing state power into a confrontation on a terrain that was differently configured through the migrant mobilizations of 2006, therefore, even citizenship itself was arguably dispensed with. Indeed, I would submit that these mobilizations have much to teach us about a politics that refuses to be a politics of citizenship ("alien," “illegal," "activist," "insurgent," or otherwise).

The state's abjection of migrants was met with a politics of incorrigibility that truly rendered unintelligible the state's very categories of distinction and discrimination. Thus, at least temporarily, within the context of these mass mobilizations, migrant "illegality" and even deportability were likewise nullified. This of course is not to pretend that the authorities of the state could not have assailed one or another individual on these grounds. Nor is it to suggest that any of the migrants engaged in the struggle ever imagined, even for a moment, that the brute consequentiality of their immigration statuses could be so wistfully transcended. Rather, it is to say that the serial insurgencies of tens and hundreds of thousands, and finally, of literally millions, abruptly altered the balance of forces, and migrants emerged as a force that could assert: We are here-in spite of our "illegality"; We are here, we do not apologize, and we do not plead for clemency; We are here, we do not hide-in spite of our deportability; You can try to deport us-but you will never get rid of us! This politics of incorrigibility, I want to insist, articulated a queer politics of migration. That is to say, it was a politics that defied and rejected all of the normative categories of state sovereignty and its immigration regime: We're here, we're queer, get used to it!

Here, it is useful to clarify and specify what epistemological and political work the analytical category queer is intended to do in the argument of this essay. I follow the instructive lead of Samuel Chambers, who only half-ironically declares the importance of being "old-fashioned" about the term queer (2009, pp. 1-2). As Chambers clarifies, there has been "a continuing tendency to falsely equate lesbian and gay with queer" and moreover, an increasing trend toward reducing queer to a mere term of inclusivity, "a rather monstrous construction" whereby it becomes "a catch-all to describe the identity of any and every individual who somehow is not now, or someday will not be, heterosexual.” Instead, Chambers announces the need to "depart fundamentally" from "the notion that 'queer' is a term of inclusivity," and insists that queer politics is "a politics that both identifies and remains committed to the impossibility of inclusivity" (p. 2; emphasis in original; cf. Gamson, 1995; Phillips, 2009). Chambers follows David Halperin, who stipulates that the term queer is precisely not "rooted in the positive fact of homosexual object-choice" and instead "acquires its meaning from its oppositional relation to the norm"; Halperin (1995) continues: 
Queer is by definition whatever is at odds with the normal, the legitimate, the dominant. There is nothing in particular to which it necessarily refers. It is an identity without an essence. "Queer," then, demarcates not a positivity but a positionality vis-à-vis the normative-a positionality that is not restricted to lesbians and gay men but is in fact available to anyone who is or feels marginalized because of his or her sexual practices.... "Queer" ...describes a horizon of possibility whose precise extent and heterogeneous scope cannot in principle be delimited in advance. (pp. 62; emphases in original)

Whereas LGBT politics—signalling lesbian, gay (male), bisexual, and transgender categories of sexual identity-is a politics directed toward the inclusion of diverse (positive) categories of gender and sexuality, in other words, the negative relationality of queer politics supplies a recalcitrant challenge to, and subversive resistance against, dominant and debilitating normative categories of gender and sexuality. Queer politics, simply put, is a counter-normative (sexual) politics of unapologetic and anti-assimilationist non-conformity.

Queer politics seeks not to be integrated within an existing economy of normative and normalizing distinctions, but rather to sabotage and corrode that hierarchical order as such. As Siobhan Somerville crucially explains, "Anchoring queer approaches exclusively or primarily to sexual orientation does not do justice to the potential reach of queer critique, which would destabilize the ground upon which any particular claim to identity can be made” (2002, p. 787). Precisely for this reason, queer politics may be understood to signal what Chas. Phillips has aptly depicted as “a turbulent creativity," which "does not yield to ... cries for tolerance, recognition, and inclusion” (2009, p. 2). Rather than a form of (sexual) identity politics, then, queer theory aspires to repudiate altogether identity-based liberal political theory, generally (Chambers, 2009), and queer politics presents an incorrigible and intractable reply to neoliberal identity politics, in particular (Phillips, 2009). Without wanting to dissipate the sexual specificity of queer critique as such, but nonetheless following the instructive lead of these queer theorists, I aspire here to borrow the destabilizing force of queer politics for the purposes of exploring a politics of migration that exceeds the normative confinements of citizenship altogether and subverts the fetishized fixities of identity outright. Put somewhat differently, I want to ask a question about the politics of human mobility, generally, that foregrounds a practice of freedom that can never be recuperated to the constituted status (or even the dynamic practices) of citizenship, which emphasizes freedom as an exercise that is never reducible to something so objectified and delimited as "rights," and which likewise refuses to attach itself to any positive, thing-like (naturalized) "identity" as such.

In this spirit, and in a manner very much akin to what I am seeking to accomplish in this essay for the "Aquí estamos" chant, Chambers (2009) seeks to elaborate a rigorously "queer" interpretation of the slogan, "We're here, we're queer, get used to it!” As in Chambers' parallel endeavour, I seek to theorize the "Aquí estamos” chant as an articulation of struggle, to ask what the best-known slogan associated with the migrants' mobilizations of 2006 might illuminate about the actuality of these real struggles of migration. It is urgently necessary to discover what this organic expression of the movement may have to teach those of us who would presume to supply it with an adequate theoretical formulation, indeed, to reveal how our critical 
aspirations themselves must follow the theoretical lead of these practical struggles. As I have already suggested, neither the migrant nor the queer chant articulates itself as a demand or a plea; neither makes any claim for inclusion. Indeed, as Chambers makes explicit, it is not even properly apprehensible in terms of a negative dialectics of recognition, which would "run the risk of reducing it to the standard formula of minority identity politics" (p. 17n5). Queer sexual practices and pleasures manifest a kind of non-conformist and non-compliant freedom that, within the socio-political order of heteronormative patriarchy, can only be classed as an abject excess generated systemically by that order's naturalized hierarchy of distinctions and discriminations. They are not even properly objectified "sexualities," as such, which might thereby be "incorporated." The queer injunction, "Get used to it," Chambers contends, "is not a call for recognition as normal, but rather an insistence that deviation from the normal will persist. After all, what 'we,' as those who hear the chant, are supposed to 'get used to' is precisely the fact that 'they' are queer-not that they are like us but that they never will be" (p. 12). The incorrigibly radical stakes here are plainly not simply a "progressive" transformation of what is deemed "normal” but instead a conclusive abolition of all normativity, as such. Analogously, in the migrant mobilization chant, the assertion "we're not leaving" and, furthermore, the promise to return in the event of expulsion, is tantamount to a declaration that short of an utter and universal abolition of state borders, "illegality" cannot be expunged under any circumstances.

Alongside other demands (most notably, the always-contingent and inherently partial demand for "legalization"), here, then, was a cacophonous and incongruent assurance that the "illegality" of undocumented migrants is endemic and, within the socio-political order of "national" state sovereignty and border enforcement, will indubitably persist. Thus, many migrants, especially the undocumented, could adopt a disconcertingly candid, sober, and above all realistic assessment of the sociopolitical fact of their unforgiving abjection. They thereby defiantly rejected the implausibly utopian mandates of assimilationism in favour of an irredeemably queer (non-normative) politics. That is to say, rather than seeking recognition or exoneration, this aspect of the movement boldly affirmed: We're here, we're illegal, get used to it! Rather than a politics of citizenship and inclusion, then, this migrant mobilization chant revealed the intrinsic parochialism of any formulation of citizenship.

\section{Incorrigibility: The Politics of Anti-Identity}

Recent attempts to reinvigorate the ongoing theorization of queer politics-notably, the essays by Chambers and Phillips which I have cited-have taken an instructive cue from the philosophical work of Jacques Rancière (1992, 1995, 2004, 2006). For Rancière, the very category "politics" is guarded as something comparatively rare and extraordinary. It does not merely refer to those arenas in which subjects pursue their competing interests, negotiate disputes over resources, and otherwise engage one another within the given parameters of a dominant system of distribution in order to obtain more power, wealth, recognition, or prestige. This sphere is what Rancière variously calls "the order," "the count," or most tellingly, "the police." Politics, on the other hand, rather than participation in this game of order, instead 
refers to the radical disruption of such an order, precisely by the unwelcome and unseemly interventions of those who literally have no place within it-those who, from the standpoint of order, truly do not exist-those who comprise "a part that has no part.” Rancière summarizes his understanding as follows:

You can count the community as the sum of its parts—of its groups and of the qualifications that each of them bears. I call this way of counting police. You can count a supplement to the sum, a part of those who have no part, which separates the community from its parts, places, functions, and qualifications. This is politics.... (2004, p. 305; emphasis in original)

"Political subjects," therefore, are only truly political for Rancière insofar as they are "surplus subjects." As he explains, "They inscribe the count of the uncounted as a supplement” (2004, p. 305). The "supplement" is a kind of excess: it exceeds the limits and constraints of the existing order.

From this standpoint, then, genuine politics tends to be exceptional, extraordinary, and intrinsically unsettling. Politics, then, can only be about the queer and incorrigible incoherence that produces a crisis within the presumed normative "order" of normal "existence." As Phillips adds, in his elaboration of Rancière's distinction:

\begin{abstract}
A political moment is witnessed only when a discrepancy arises between, on the one hand, the counting of different parts in the order and, on the other hand, the existence of those parts. This discrepancy results in a confrontation between a party or order that exists, and one that does not exist. The discrepancy built into the order escapes the ordinary measurement of things and comes to a head at a particular moment, exposing this miscalculation of parts equaling a whole.... Order is the background from which politics emerges, reconstituting the ruptured arrangement of parts. (2009, p. 3)
\end{abstract}

Importantly, politics for Rancière is therefore about the disruption that transpires when "those who have no part" become paradoxically manifest as the un-counted part that produces a crisis of order by exposing a fissure within its fabric (1995/1999, pp. 14-15). Indeed, this formulation has striking resonances with Kristeva's formulation of the abject as that part which is "rejected [but] from which one does not part," thereby throwing system and order into disarray, and threatening identity and meaning itself. Likewise, the theme of nonexistence in Rancière clearly articulates as well with Susan Coutin's instructive elaboration of migrant "illegality" as entailing a space of juridical "nonexistence," whereby undocumented migrants' substantive physical and social presence (or, existence) is contradicted and riddled by their official legal negation and the systemic erasure of their legal personhood (2000, pp. 27-47, 2003).

The insurgencies of those with no part name the miscount and enunciate it as a wrong, and in so doing, according to this schema, those of no-count literally conjure themselves into existence by making an unseemly appearance within the now disrupted and newly unstable order. This is what I am contending was at stake in the migrant mobilizations of 2006, wherein those who were presumed to have no apprehensible existence of any consequence to the existing order of things asserted 
an uncanny existence (Aquí estamos!), which exposed a glaring discrepancy in the police order of state sovereignty, citizenship, and business-as-usual. However, it is crucial here to appreciate that, for Rancière, the uncounted do not thereby simply ask to be counted (included). Indeed, the very ability to make such an appeal would indicate that they have already been incorporated as part of the count, albeit in some plainly disadvantaged or subordinate fashion: this is the routine stuff of ordinary disputes over inequality. As Phillips explains:

Making such a request would require not only mutual acknowledgement of the existence of parts without a part, but also a shared language between those non-parts and the dominant order.... the count is everyone who exists, not everyone who is included.... Both the have's and have-not's are within the count; the type of disagreement between them is of a different nature... In fact, inequality within the count is a result of a more fundamental equality: everyone who is in the order is equally existent. (2009, p. 4)

Queerness, then, derives its precisely queer/political force from a kind of unintelligibility within the order (Chambers, 2009), and is specifically grounded in "the incommensurable conflict over the count. Policing is the attempt to eliminate this conflict” (Phillips, 2009, p. 3). This is why queerness cannot be reduced to a mere catch-all category that aspires toward an inclusivity otherwise beleaguered by the proliferation of positive sexual identities, such as "gay" or "transgender." What makes queer politics both specifically queer and distinctly political, in these Rancièrean readings, is its negativity. This, moreover, is why the awkwardly liberal notion of "queering the state" (Duggan, 1994) is deeply misguided (see, e.g. Puar, 2007; Puar \& Rai, 2002). ${ }^{8}$

Queerness (unlike "homosexuality,” for instance) audaciously asserts the existence of something fundamentally unintelligible, incommensurable, incompatible, and finally inassimilable. And indeed, what makes it political is the irreducible fact that it is incorrigible. As I have sought to demonstrate, this is exactly the same bold and unabashed position that the migrant mobilizations adopted as their single most characteristic gesture: We're here, we're illegal, get used to it! Or, to put it in Rancière's terms: We are the part that has no part; yet, we are here, we exist-and we're not going anywhere! Indeed, another migrant mobilization chant invokes the ambiguities and ambivalences that are suggested by the Rancièrean problematic of "the count," explicitly: No somos uno, no somos cien; Somos millones; iCuéntanos bien! [We're not one, we're not a hundred-we're millions; Take a good count of us!]. ${ }^{9}$ One could detect here the workings of a more prosaic and predictable notion of the "democratic" desire to be counted, and thus, something like a prefigurative politics of incipient citizenship (perhaps insurgent, but nonetheless strictly intelligible according to the normative logic of the dominant political order). Taken this way, this indeed would be an analogous gesture to the sorely vexed slogan, “Today we march, tomorrow we vote." Nevertheless, there is also a kind of menacing gambit, which dares the order of the police: Count us - IF you can! According to this more incorrigible logic, the migrant multitude acknowledges the political rationality of "the count," only to underscore its flagrant and flamboyant disregard for it. Here, migrants effectively proclaim (and demonstrate) their own uncountability, their "countless"-ness. To announce "We're millions" is in fact not to 
stipulate a real (literal) count so much as to incite the collapse of the official count. It affirms the impossibility of counting this disruptive but unmistakably enormous part that has no part within the count. Such a challenge accompanies the parallel assertion that the ever-deportable mass of undocumented migrants is so innumerable that they truly could never be expelled (deported), under any circumstances. More fundamentally, however, this assertion inflames a real situation in which countability has become unintelligibility, and in which migrants can audaciously proclaim: We're not going anywhere; you can't get rid of us.

The "we" that is posited in this queer politics of migration, however, does not affirm the existence of a positive constituency. In spite of agonistic slogans, such as "Today we march, tomorrow we vote"-which for the vast majority of undocumented migrants is utterly implausible, and thus readily recognizable as fanciful and vacuous-most of those who took to the streets in protest were not going to be easily marshalled as any sort of electoral bloc within the existing order of the U.S. state. Nor does the "we" that migrants asserted uphold the existence of an "identity," as such. Certainly, within the migrant multitudes, there was ample evidence of a remarkable heterogeneity, predictably enough comprised of a vast array of specific racialized and national-origin categories and sub-categories of "foreign" identity (albeit with Latinos-and more specifically, Mexicans-playing an indubitably preeminent role). There is no denying, moreover, that particular organizing efforts sought precisely to assert that these migrants' insurgent energies could and would be domesticated for the purposes of various more predictable minoritarian political projects. But to be migrants — and to be "illegal" migrants, in particular-is a strictly relational, and in this sense, negative, identity (constituted in and through a social relation that is finally contingent). There is nothing positive, essential, or cohesive about it which could coalesce around any sort of distinct "group" or "population," and it is crucial to rigorously avoid the trap of endorsing culturalist notions of a generic "immigrant experience" (what I have elsewhere designated as "immigrant essentialism"; see De Genova, 2005, pp. 56-94). Instead, migrant status ("authorized" or "illegal") entails a spectrum of juridical and sociopolitical relations to the state, and must be actively and more or less deliberately produced through the law and its enforcement. Thus, a queer and sundry assortment of different identities came to be bundled together through the mere commonality of belonging, however haphazardly, to that category that is the part of no account- the disposable, ever-deportable mass of migrants with debased, negligible, or no legal personhood whatsoever, who from the standpoint of the dominant order of citizenship, simply do not exist.

These migrants' exuberant and outspoken proclamations of their existence-their presence, their "here"-ness, indeed, their "we"-ness-and the incorrigibility they celebrated in their defiant refusal to be silenced, suppressed, or expelled, therefore, can only be apprehensible as a politics of anti-identity. This more contingent "we" had nothing positive in common-within the U.S. political order-except their negative relation to the machinery of the state, which reduced them all to rightless denizens and de facto "suspects." Like Halperin's depiction of the meaning of "queer," this was "an identity without an essence ... not a positivity but a positionality." On the other hand, if there was nonetheless an alternative sort of positivity at stake here, albeit only an incipient one, it congealed around the "we" that was apprehensible only within the global social relation of labour and capital- 
the positive "we" of labouring humanity, as yet unnamed and finally reducible to no “identity” as such (De Genova, 2010b).

This negative space of relationality, in contradistinction with the positivity of identitarian positions and attachments, can be affiliated to another concept in Rancière. "Political subjects," he argues, “... are always defined by an interval between identities, whether these identities are determined by social relations or juridical categories.... Political subjects exist in the interval between different names of subjects" (2006, p. 301; emphasis added). In other words, subjects may be activated as genuinely political subjects, according to Rancière, only when they operate from a position that is not reducible to the given terms and coordinates of already cognizable and thus, actually existing identities. In this sense, as Dimitris Papadopoulos and his colleagues (2008) have argued, these politics often involve a long incubation during which they remain relatively imperceptible. Accordingly, politics erupts from that incipient and often elusive space of non-identity, the interval defined by non-existence: its eruption is radically new, hitherto un-accounted for, unpredictable and unanticipated, and it interrupts the order of things with an odd (queer) supplement, an excess that, strictly speaking, does not belong and has no place. Politics, then, is indeed not a matter of accommodating and integrating otherwise aggrieved identities, not a matter of "inclusion" at all. Instead, it is about the crisis that ensues from the abrupt and troublesome appearance of that which officially does not exist, cannot be counted or recognized, and makes unruly claims that are essentially unintelligible within the order of the police: Here we are, we're illegal-come and get us ... but if you do, we'll come right back!

\section{Nationalist Compulsions and the Global Politics of Transnational Mobility}

A genuinely critical scholarship of migration must in fact be addressed to the task not merely of describing but also theorizing —and critiquing-actual struggles, the real social relations of unresolved antagonism and open-ended struggle that continuously constitute social life. Here, it is crucial to specify that the very notion of "society" - the reified and fetishized "thing" that tends to be casually called "society"-involves an uncritical presupposition whereby the presumed "object" of social analysis is objectified on precisely a "national" spatial scale (Hindess 2000; Holloway 1994). This is symptomatic of what John Agnew (1994) has depicted as one of the enduring effects of "the territorial trap" of contemporary political thought. As Neil Brenner and his collaborators note, "this establishes the national scale as the ontologically necessary foundation of modern political life” (2003, p. 2). ${ }^{10}$ These epistemological and methodological problems are especially pertinent to migration studies (De Genova, 1998, 2002, 2005; Wimmer \& Glick-Schiller, 2003). Indeed, as Willem Schinkel (2010) has argued, the very notion of "integration" operates more generally as a decisive and routine short-circuit through which a (territoriallydefined, "national”) "society" may be produced and stabilized as a delimited object with determinate boundaries demarcating its putative inside from its constitutive outside (cf. De Genova, 2007b). The very processes of state formation and their compulsive nationalization must consequently be seen as part of what is in fact generated through the social struggles surrounding transnational human mobility and 
the political conflicts of "immigration," whereby the figure of "the immigrant" is produced as an object of U.S. nationalism (De Genova, 2005, pp. 56-94).

Nonetheless, these struggles operate within the fetishized (apparently fixed and durable) parameters of already-constituted (reified) state formations and their regimes of "legality" and "illegality." All migrations, after all, are composed as historically specific products of the intersections of particular formations of human mobility (migratory movements) with the distinct political and legislative histories of particular states and their consequent legal economies of meaning and differentiation (De Genova, 2002). Part of what is at stake in these struggles, however, is no less than the state itself. For, the subordination of (deportable) migrant labour is a decisive and perennial task in the expressly "political" mediation (by territorially-defined, "national" states) of the global capital-labour relation (De Genova, 2010a, 2010b; cf. Holloway, 1994). Hence, this essay has hitherto referred in a relatively unproblematized way to the 2006 mobilizations as having taken place and been substantively located "in the United States." But it is quite relevant to note that this movement, much as it was centrally preoccupied by the legislative horizon affecting the juridical status of migrants within the space of the U.S. nation-state, had transnational repercussions and ramifications, as it inspired parallel mobilizations in a variety of other sites across Latin America (Robinson, 2006). Still more important, the struggle of these transnational migrants radically intervened in the ongoing (re-) composition of the tempos and tenor of the U.S. state's politics of "immigration" and law-making. Thus, what is at stake here is not simply the analysis of socio-political processes "in" the United States (as if they could be apprehensible as effectively contained within a durable receptacle known as U.S. "society"), but rather the critical theorization of a transnational social relation of labour and capital and the global politics of migrant mobility as constitutive of the contemporary United States as such (De Genova, 2007b). The critical analysis of the 2006 migrant struggles, then, can illuminate a more encompassing interrogation of the historical specificity — in the present — of the United States as a state formation, of the particular manifestations of its politics of immigration, of U.S. nationalism and nativism, and the full gamut of its nationalist compulsions. Furthermore, what manifests itself here as an eminently "political” struggle between migrants and the U.S. state, in particular, must therefore always be apprehensible as simultaneously an insubordinate mobilization of (transnational) migrant labour against the more generalized terms of its subordination to (global) capital. It is not tenable to imagine that this overtly "political” insurgency of migrants "in” the United States is somehow a matter of no consequence to capital. The nationalist compulsions through which politics tends to be fought out in actual struggles, especially with regard to "immigration" within the space of a specific "national" state, must always be critically conceptualized in terms of the global politics of the capital-labour relation. In this respect, the transnational mobility of labour-like all labour under capitalismnecessarily has a double character, as (effectively subordinated) labour-for-capital while always also potentially labour-against-capital, which is never pre-determined and remains ever unpredictable and volatile. 


\section{“Illegality” and Incorrigibility}

The ultimately abortive Border Protection, Antiterrorism and Illegal Immigration Control Act plainly made a central target of undocumented migration and "illegal aliens." Predictably, therefore, the positive demands of the movement commonly included various formulations of "legalization" for undocumented migrants. However, the proposed law notably included abundant provisions not only for the outright and summary criminalization of the undocumented but also for the manipulation of myriad technicalities in the corpus of immigration law as pretexts for the illegalization of otherwise "legal" (and generally law-abiding) non-citizens. It actively and aggressively sought to blur the bright lines between "legality" and "illegality," in other words, in favour of a massive degradation of the social and political condition of all migrant denizens, as such. Thus, the bill's bluntly punitive and repressive features served to instigate an otherwise improbable coalescence and cohesion among juridically divergent categories of migrants, which might previously have been effectively disabled by the invidious and divisive dimensions of immigration law's economy of distinctions and discriminations. Thus, a kind of improbable "we" crystallized precisely through the negativity of this common act of refusal. Nevertheless, the premier focus of all the protests, as a consequence, was to simply but audaciously denounce the purportedly "antiterrorist" immigration law. This means that much of the actual content of the protests acquired a distinctly plaintive tone.

The predominantly defensive character of the struggle was amply evident in the abundance of slogans that tellingly revealed the movement's more generally beleaguered sensibility, such as the agonistic and preemptively compromised proclamations, We Are Not Terrorists, and We Are Not Criminals. These sorts of migrant complaint are inherently compromised, I contend, because by responding in kind to the offending allegations of the dominant nativist metaphysics of suspicion, they are induced to inhabit the same discursive terrain. Their strictly defensive posture within this arena of discourse inevitably compels them to verify its premises and uphold its conceits: in short, they seem to reply, there really are "suspect" migrants, the affinities between "crime," "terrorism," and "immigration" are genuine, palpable, and legitimate concerns - it's just that ... “we are innocent!" Thus, these migrant respondents asserted that the conjuncture of the Homeland Security State's metaphysics of antiterrorism with "illegal immigration" was simply misguided and misplaced. These were the sorts of reply that seemed to say, "We may be 'illegal,' but otherwise we are truly innocent, good, deserving, and in effect, legitimate 'immigrants'." In the worst scenario, some (Latino) migrants during the 2006 mobilizations even volunteered themselves as accomplices, in effect, of the security state's ostensible "war against terrorism": they fashioned themselves as its would-be advisors, waving placards that only half-ironically declared, The 9/11 Hijackers Did Not Speak Spanish. Thus, alongside and against the politics that promoted an expansive, negative (anti-identitarian) "we" encompassing the full spectrum of the deportable, here was a positive, specifically Latino (and in this instance, reactionary) identity politics of denouncing "terrorists" (the proverbial “9/11 hijackers”) as non-citizens who "did not speak Spanish.” The transparent sarcasm notwithstanding, these sorts of gestures could only uphold anew the presumed sanctity of the tasks of counter-terrorism that had by now become the 
paramount mandate of the immigration authorities. And they reaffirmed the dominant insinuation of a racialized logic of suspicion and culpability which figured Arab and other Muslim non-citizens as de facto enemy aliens (De Genova, 2007a; cf. Ahmad, 2002, 2004; Bayoumi, 2008; Cainkar, 2002, 2003, 2004, 2005; Chon \& Arzt 2005; Cole, 2003, pp. 47-56; Daulatzai, 2007; Fernandes, 2007; Human Rights Watch, 2002; Maira, 2004, 2009, 2010; Puar, 2007; Puar \& Rai, 2002; Saito, 2001; Volpp, 2002).

In the same spirit of conformity with the dominant ethos of a besieged but reanimated U.S. nationalism, there was likewise an extraordinarily vociferous and emphatic effort by the more conservative elements in the 2006 struggles to insist that protesters should carry U.S. flags, as a sign of "loyalty" and as a testament of the assimilationist desire to truly "become Americans." In these debates within the movement, the explicit referent was the customary profusion of flags representing the migrants' diverse countries of origin, which would purportedly have served to merely verify the worst nativist suspicions of the anti-immigrant lobbies (cf. BakerCristales, 2009; Pulido, 2007). More controversial but similarly compromised by U.S. nationalist prerogatives was the release on April 28, 2006 of "Nuestro Himno" ["Our Anthem”], a Spanish-language rendition of "The Star-Spangled Banner" (the U.S. national anthem). Distributed to Spanish-language radio stations on the eve of the May 1 demonstrations, the song was intended to serve as an anthem of solidarity for the movement, and was quickly disparaged as verifying an anti-assimilationist repudiation of genuine "Americanness." Anti-immigrant columnist Michelle Malkin, for instance, decried it as "the Illegal Alien Anthem."11 Migrant "illegality," then, remained the hard kernel around which circulated all these competing and conflicting projects of negotiating the boundaries of U.S. national identity, either surveilling and superintending the high premiums of nativist intolerance and hostility, or magnanimously seeking to "assimilate" the iconic "bad immigrant" (the undocumented) into the hallowed xenophilic aura of the proverbial "good" one, which serves to verify for U.S. nationalism the resilient choice-worthiness of an “Immigrant America” (Honig, 1998, 2001, pp. 73-106; cf. De Genova, 2005, pp. 5694).

The migrant struggle of 2006 was thus pressed to respond to the enduring and ever more fanatical fetishization of "illegality" as a presumptively obnoxious affront to, and unpardonable transgression of, the sanctity of the space of the state. Yet, for precisely this reason, the other politics of the movement, with its robust, repeated, and insistent declaration-Here we are, and we're not leaving! And if they throw us out, we'll come right back! — commands serious reflection. For, this other politics was the indeed the (anti-assimilationist) politics of the migrant struggle's irreducible and incorrigible otherness. This slogan is readily apprehensible within the U.S. "national" context, of course, and may even be recuperable for various more conventional assimilationist projects; in effect: We're here, our inclusion is already an irreversible fact, so our integration and assimilation must be embraced; in any case, they are inevitable. But there is a radical open-endedness operative here, which defers and effectively silences the question of assimilation altogether-as finally irrelevant: Whatever we may become, we're not going anywhere-here we are, here and now.

It is useful, furthermore, to reframe this affirmation of migrant presence-both literally physical and socially substantive presence within the space of the U.S. nationstate-as also the enunciation of a global mobility. It overtly proclaims itself to be 
unapologetically "here," but the promise to return in spite of deportation also boldly signals, by implication, a kind of ubiquity, which is accomplished in and through mobility-in effect, declaring: We are everywhere. Indeed, the defiance that migrants in the United States asserted and the resilience that they celebrated were tantamount to announcing: We are free in our movement and through our movement-and by means of our mobility, we elude your efforts to control our movement and contain our freedom. Here, in short, was a politics of migration that exceeded the prescribed "politics" of "immigration," a global politics of transnational mobility, an excess that could not be domesticated and refused to be incarcerated within the space of the U.S. nation-state. Actual migrant presence within the space of the U.S. state was thereby coupled with the omnipresent potentiality of more migration, signalling the global horizon of a migrant "presence" beyond the borders of the state, which remains always possible and merely awaits its own mobilization as migration-in-fact (De Genova, 2010b). Here, in other words, was a vibrant expression of the autonomy of migration. ${ }^{12}$ Alongside the variety of other more conventional efforts to deflect the allegations of "undeservingness" affiliated to their "illegality," therefore, here was an enthusiastic and recalcitrant affirmation of migrant mobility, as such, and a veritable embrace of de facto "illegality" itself. This slogan thereby suspended the compulsory nationalist question of "assimilation" altogether, negating its pertinence and repudiating its validity: We are who we are, and what we are; we're here, and there's nothing you can do about it. Furthermore, they seemed to assure the authorities: We're here today, may be there tomorrow, but will be back here again thereafter-Catch us if you can! Simply put, it was an exuberant proclamation of incorrigibility. As some migrants made explicit, We're illegal—so what? (McNevin, 2009, p. 74; for analogous examples from the 1990s, see De Genova, 2005, pp. 238-239).

\section{“Immigrants’ Rights” ... and Migrant Rightlessness}

At the outset of this essay, I deliberately depicted the two chants-Aquí estamos...and We're here, we're queer...-not as "immigrants' rights" or "gay rights" (much less, "queer rights") slogans, but rather as the respective expressions of migrant and queer mobilization. That is to say, they erupt from mobilities which cannot be fixed into place, categorized, and regimented. They refer us to practices and processes of open-ended becoming that actively produce and transform space, not fixed identities or knowable "objects" to be put in their place. Furthermore, I have emphasized the significance and salience, for interpretive and analytical purposes, of the fact that neither chant advances anything on the order of a demand. Neither slogan is a claim for "rights," and neither appeals in any simple or straightforward sense for "recognition" (much less, for "representation"). To follow further the logic of the earlier discussion of Rancière, these are political enunciations precisely because they do not seek inclusion within the existing order of rights, privileges, and entitlements, and do not even seek to be intelligible within that framework of assumptions. Inasmuch as, by means of these slogans, "illegal aliens" and queers are satisfied to simply announce their existence and boldly affirm their abject presence-come what may, all conceivable recriminations and repercussions notwithstanding - they operate according to an altogether different, antiassimilationist logic of struggle, for which and through which freedom is a practice 
consummated by its own exercise. Rather than making claims for rights, these interventions complement irreconcilable antagonisms with incorrigible alterity. They make no pretence of the possibility of reconciliation. They are the irruption from within of an irreducible "outside," an inassimilable excess, which seeks no integration within the system of their own loathsome abjection. Thus, they menace that system with the collapse of its own normative meanings and coherence. If they make claims, moreover - even if only by implication - they are tantamount to the sorts of claims that ultimately demand the utter collapse of the whole normative order.

In a socio-political context of legislative assault against the residual semblances of migrant legal personhood, escalating border militarization, and intense securitization, the very notion of "immigrants' rights" is really rather peculiar, if not completely oxymoronic. Indeed, the very idea of “immigrants' rights” instructively exposes some of the constitutive contradictions of the regime of citizenship itself and of “rights,” more generally (De Genova, 2007a, 2009, 2010a, 2010b). As I would like to explicate in this concluding section, what I have designated to be the queer politics of migration is articulated alongside of — but fundamentally at odds with-this vexed concept of "immigrants' rights." If the migrant mobilizations of 2006 verified anything, it was plainly that deportable non-citizens, those migrant denizens officially relegated to a juridical status and social condition of ever more brazen and abject rightlessness, could never thereby be so casually dispossessed of their political prerogatives and their resilient resources for struggle. Their potential power and creative capacities as a genuinely political force was in no way reducible to their official (juridical) position of disability, as explicitly and sanctimoniously stipulated within the order of the police.

It is predictably symptomatic of political struggle in the United States, in particular, that the migrant mobilizations seemed to be almost exclusively focused on these legalistic questions of "rights," "illegality," "amnesty,” and "legalization,” and citizenship, more generally (but only in its narrowly juridical register). That is to say, the migrant mobilizations were quickly celebrated-perhaps prematurely, and in any case without much critical reflection-as a "new civil rights movement" (see, e.g. Chacón \& Davis, 2006, p. 7; Johnson \& Hing, 2007), in spite of the flagrant and preemptive ineligibility of migrants for any of the putative rights of citizens. Yet, there was virtually never any dispute over the substantive social conditions of migrants' marginalization, their material deprivation and real misery. Poverty was a relatively subdued if not completely silenced theme in these debates. Notably, the sorts of disputes over migrants' widespread impoverishment as racially subjugated "minorities," which might be pertinent to classic "civil rights" controversies concerning "second-class" citizenship, tended to be simply disregarded as irrelevant. Here, one recalls the preemptive terminology of the dominant anti-immigrant nativism: "What part of 'illegal' don't you understand?" Thus, against the hostile contention that migrant "illegality" renders any claim to "justice" effectively groundless, pro-immigrant advocates have tended to side-step these social questions in favour of a straightforward faith in "legalization." It is as if some sort of merely juridical remedy to migrants' "illegal" (deportable and rightless) condition would presumptively remove an onerous barrier and instantaneously make available to them the mythic upward social mobility ladder of canonical U.S. nationalist narratives about the "land of opportunity" (Chock, 1991). In this respect, the 
legalistic preoccupations of these struggles remained recuperable to the hegemonic xenophilia, in Bonnie Honig's insightful phrase (1998, 2001), which animates liberal U.S. nationalist discourses of "immigration” (cf. De Genova, 2005, pp. 56-94). Thus, liberal advocates for migrant "legalization” and "immigrants' rights” could remain dutifully (if perhaps often unwittingly) faithful to the U.S. nationalist conceits and presuppositions regarding the promise of "Immigrant America" as a refuge of liberty and a haven of boundless opportunity.

In contrast to the statist and nationalist recuperation of migrant insurgency as a matter of "civil rights," others have discerned in the mobilization of transnational migrants an occasion for the reinvigoration of the sense and substance of "human rights.” Indeed, the quite pervasive slogan No Human Being Is Illegal would seem to suspend the pertinence of "the law"-specifically, the worldly and parochial preoccupations of the immigration laws of nation-states - in favour of a "higher" (moral) imperative, grounded in the universalism of a presumably irreducible substantive fact of humanity, as such (Agamben, 2003). ${ }^{13}$ The agonistic plea of this slogan effectively responds to the socio-political reality of one or another state's illegalization of migrant non-citizens with the recuperation of these particular persons (and their specific relations to state power, sovereignty, and borders) as putatively "rightful" members of a universal (human) constituency. Such a slogan thereby invokes the spectre of a "law" that is greater than any particular state's immigration law — by implication, at least, a ("natural") "law" that finally must be grounded in the pure "nature" of human birth, or nativity, as such (cf. De Genova, 2010b). Yet, what is perhaps even more problematic for the purposes of this essay is that this slogan can also be read to proclaim, in effect: All Human Beings Are Legal. The gesture toward "human rights," then, entails a veritable desire for the law. ${ }^{14}$ In this sense, these wistful invocations of undocumented (officially rightless) migrants' putative "human rights," insofar as they operate as a grand affirmation of an ethereal ideal of "legality," remain trapped within the logic of sovereign state power. Thus, the project of configuring the struggles of migration as an iconic paradigm for "human rights" advocacy is finally one that is deeply ensnared within the rather more pernicious and ordinarily unexamined horizon of a global (supra-national, imperial) sovereignty.

One could read Rancière in support of such contentions about "human rights," but only in a distinctly queer, paradoxical manner. As I have briefly outlined, Rancière conceives of politics as the content of "specific scenes of dissensus" in which subjects who are officially deemed to not exist, paradoxically, nonetheless enact a "supplement" to the official "count" of the dominant order (2004, p. 305). He goes on to assert that the Rights of Man (or "human rights," so to speak) are indeed nothing less than the rights of these political subjects, those of no-count, who do not exist until they activate this dissensus and unsettle the order of the police. Rancière argues that this is why ...

even the clandestine immigrants in the zones of transit of our countries or the populations in the camps of refugees, can invoke [the Rights of Man]. These rights are theirs when they can do something with them to construct a dissensus against the denial of rights they suffer. And there are always people among them who do it. (2004, pp. 305-306) 
In answer to the question "Who Is the Subject of the Rights of Man?", then, Rancière declares, in effect, that it is this hitherto un-counted subject, non-existent and of no account. Accordingly, the ostensible subject of human rights is the "surplus subject" who produces a dissensus, the supplemental miscount in which the part that has no part inserts itself and disrupts the order. Politics therefore ends up being largely a polemic about the verification of the Rights of Man. As Rancière explains:

Ultimately, those rights appear actually empty. They seem to be of no use.
And when they are of no use, you do the same as charitable persons do
with their old clothes. You give them to the poor. Those rights that appear
to be useless in their place are sent abroad, along with medicine and
clothes, to people deprived of medicine, clothes, and rights. It is in this
way, as the result of this process, that the Rights of Man become the rights
of those who have no rights, the rights of bare human beings subjected to
inhuman repression and inhuman conditions of existence. They become
humanitarian rights, the rights of those who cannot enact them, the victims
of the absolute denial of right. For all this, they are not void. ... The void
is filled by somebody or something else. The Rights of Man do not
become void by becoming the rights of those who cannot actualize them.
(2004, p. 307)

Thus, acknowledging the apparent emptiness of "human rights," Rancière suggests that it is precisely this emptiness that makes them viable for those who activate politics from a space of non-existence. From his critical vantage (and explicitly critiquing Hannah Arendt's classic account [1951/1966, pp. 267-302]), "rights" that are substantively empty are not in fact void-because their specifically political substance paradoxically derives from their activation of a dissensus that erupts precisely from a void, a condition of nonexistence. Human rights are activated, for Rancière, as the besieged rights of those political subjects whose very nonexistence within the dominant order verifies the contentious polemic that they initiate. From within this paradox, however, the otherwise vacuous and beleaguered notion of "human rights" might assume an enigmatic meaningfulness, but one which can be posited only negatively, relationally - in effect, as the "rights" that matter exactly because, and only because, they are the rights of the rightless.

A deeper and far more pernicious paradox, however, resides in the utter impossibility of such a polemic over "human rights" to ever produce a material and practical grounding that is not haunted by its dependence upon some form of supranational, "universal," quasi-imperial sovereignty. At least by implication, the dissensus that provokes a new conjuncture of politics-inasmuch as it is articulated in terms of "rights"-also refers inevitably to a sort of adjudication. "By becoming the rights of those who cannot actualize them," to re-phrase Rancière's formulation, the Rights of Man operate in a void which never fails in fact to be "filled by somebody or something else." Like the more metaphorical notions of ("global," "transnational") "citizenship" which are finally inextricable from these various formulations of "rights," any attempt to capture (transnational) migrants' insurgent energies and veritable practices of freedom within the rubric of rightfulness or entitlement is doomed to exalt anew some sort of juridical order of constituted sovereign (state) power. The more virtual the latter appears, the more certain it is to be that of a global power that eludes definition according to the more conventional,

Studies in Social Justice, Volume 4, Issue 2, 2010 
territorially-defined "national" form. If the true subject of "human rights" is one deemed to erupt from a space of non-existence within the order of the police, there are likewise those constituted police powers that similarly have no sanctioned juridical place from which to activate or enforce "human rights"-except as the would-be (global) sovereign that confirms its own putative legitimacy only by deciding in fact upon what does or does not count as a "state of exception" (Agamben, 2003). "Imperial states," argues Ann Stoler, "by definition operate as states of exception" (2006, p. 139; emphasis in original). Thus, efforts (such as Rancière's) to recuperate the notion of "human rights"-precisely with recourse to the abject figure of sovereign power's definitively rightless denizens_-are ultimately unsustainable. $^{15}$

Here, we must return to the question of a global politics of labour and capital which stubbornly resists its own foreclosure within any politics of "citizenship," howsoever construed. Entangled with this matrix of "rights" and rightlessness, the themes of (transnational) migrant labour (and thus exploitation, even if only in a somewhat inchoate way), were abundantly manifest in the 2006 mobilizationsabove all, in the culminating designation of May 1 as a national one-day general strike and consumer boycott, to be known as "A Day without Immigrants" (cf. De Genova, 2009; Pulido, 2007; Robinson, 2006). The significance of the migrant movement as precisely a labour struggle was clearly signalled by this deliberate revitalization of May Day as International Workers' Day. May 1, of course, is a holiday of the global working class. In spite of the date's historical genesis in Chicago in 1886, however, May Day has been generally stigmatized and suppressed historically by the mandates of U.S. anticommunism and has, in effect, never been honoured in the United States except by radical left-labour movements. In this respect, too-exactly because an explicit politics of class struggle has been rendered virtually unspeakable in the United States-the overt and unabashed labour politics of the migrants' mobilizations entailed, likewise, a queer politics.

With recourse to a diverse spectrum of proclamations of the dignity and entitlements of labour, the 2006 movement advanced a stalwart reminder of U.S. employers' and consumers' broad dependency on migrants-as workers. Nevertheless, these agonistic assertions of migrants' entitlements and "rights" on the basis of their laborious (and by implication, docile, dutiful, and law-abiding) servitude were also plagued by their own contradictions. In particular, one very pervasive strain of migrant discourse concerning "hard work" and "deservingness" was deeply ensconced in a torturously contradictory set of allegations with regard to the "laziness," "welfare dependency" and "criminality" that many migrants commonly attribute to their most proximate competitors at the bottom echelons of the U.S. labour market, namely, impoverished U.S.-citizen racial "minorities"above all, African Americans (De Genova, 2005, pp. 167-209, 2008; De Genova \& Ramos-Zayas, 2003, pp. 57-82). Hence, a corollary to the presumably self-evident declarations We Are Not Terrorists and We Are Not Criminals presented itself in another couplet: We Are Workers, Not Criminals and the still more revealing We Are Not on Welfare. When Jennifer Gordon and R. A. Lenhardt rightly demand, in response to these slogans, “As opposed to whom?” they very appropriately note that "the seemingly positive rhetoric of the signs that many carried ... had a painful double meaning” (2006, p. 2496; emphasis in original). Here one may detect the transposition of a politics of labour as negativity, relationally ensnared within and yet 
irreconcilably against capital, into an identitarian politics of class and race, a politics of class as positive identity. In this context, "work" itself operates ideologically as an "American" value within a moral economy of citizenship, whereby the capacity for labour is affiliated to a competence for self control, self-government, and rightful citizenship through a kind of labour-republican politics of virtue (cf. Almaguer, 1994; Roediger, 1991; Takaki, 1979).

Still, alongside these positive identitarian gestures, there was the articulation of another politics - an incorrigible politics of migrant labour that took the form of a robust politics of anti-identity. Avowing their position as labour, migrants boldly upheld their "illegal" (and rightless) presence-Aquí estamos!—and their mobilizations presented the sovereign power of the state with an unthinkable aberration. Migrants answered normative allegations of "illegality" with an alternative framework for making claims-one premised upon the (global) prerogatives of labour-which thus abnegated unreservedly the pertinence of immigration law altogether. Speaking in a political idiom that was apparently addressed to the state, then, the migrant mobilizations shifted the register to address capital directly, as transnational labour. The movement seemed to simply declare: Here we are, "illegal" and without rights-but because you depend upon our labour, you are powerless to expel us; thus, we defy your power, and we're not going anywhere ${ }^{16}$ Here was an enunciation of (transnational) labour as constitutive of (global) capital, inextricably within capital, but also against capital-rightless, "illegal," but insubordinate all the same. As Marx famously noted, in the "antinomy, of right against right ... force decides” (1867/1976, p. 344). Thus, the answer to migrants' real predicament of objective rightlessness was not recourse to some alternate rubric for the restoration of rights. In this sense, migrant rightlessness was merely a "fact," and the anomalous and inimical character of this fact made the law itself an abhorrent nemesis. This aspect of the movement's unapologetic politics of (transnational) migrant labour therefore facilitated an implicit rejection of the very notion of "immigrants' rights," which was bedevilled with its own inherent inconsistencies and so compromised by this incoherence. Such gestures effectively responded to the fetishistic language of "legality" and "illegality" with another idiom that was strictly unintelligible to the law's abstract formalisms and its economy of categorical distinctions. This politics of migrant labour was a queer politics, furthermore, because it was unabashed and unreserved about this unintelligibility: it denounced the abjection and rightlessness of migrants by altogether repudiating the law and the state itself, defiantly and incorrigibly.

\section{Notes}

1 I am truly grateful to Tanya Basok for inviting me to contribute to this special issue; without her editorial initiative, I may not have had the occasion to develop the thoughts presented in this essay. Earlier drafts were presented to scholarly and activist audiences in Rome, Bologna, and Amsterdam, and I owe a note of appreciation to Nina Trige Andersen, Sébastien Chauvin, Ayça Çubukçu, Paul Mepschen, Sandro Mezzadra, Enrica Rigo, Maria Vittoria Tessitore, and Bertil Videt for their various roles on these occasions. I received very engaged critical responses to the text from Ayça Çubukçu, Ramón Gutiérrez, Engin Isin, Naledi Nomalanga Mkhize, and Nathalie Peutz, which have challenged and enriched my thinking about this essay. I also owe a note of gratitude to various colleagues and students whose theory and practice have helped me, in various ways over the years, to arrive at the 
ideas here, especially: Alejandro Amezcua, Rutvica Andrijasevic, Adriana Garriga-López, Amanda Gilliam, Marcial Godoy, María Lugones, Sofian Merabet, Sandro Mezzadra, Dimitris Papadopoulos, Joshua Price, and Marie Varghese.

2 For instances of this chant from migrant protests during the 1990s, see, e.g., Coutin (2000, p. 42; cf. 1999; 2003); Crawford (2007); Lipsitz (2006, p. 312). Indeed, Raúl Villa (2000) posits that the distinctly spatial sensibility of this declaration is "barriological” (pp. 52, 109) and reinscribes its genealogy within the history of Chicano-identified socio-cultural formations; if not necessarily referring to the phrase itself, verbatim, Villa nonetheless traces this sensibility back at least to the Los Angeles Barrio Writers Workshop / Los Angeles Latino Writers' Association of the late 1970s and early 1980s (pp. 107-109).

3 For a compilation of estimated totals for virtually all documented demonstrations, based upon the relatively more conservative reports of the official news media, which nonetheless arrives at a total participation ranging from 3.5 million to more than 5 million for all known events during the spring of 2006, see the database available at:

$<$ http://www.wilsoncenter.org/migrantparticipation>.

4 In spite of the genuine depth of the organizing that contributed everywhere to the success of the movement (see, e.g., Gonzales, 2009; Voss \& Bloemraad, n.d.), it is nonetheless undeniable that the 2006 struggles achieved their remarkable force and scope rather abruptly, with the rapid spread of an acute awareness of the particularly offensive and menacing ramifications of the new legislation.

5 In a related but revealingly discrepant context, Susan Coutin (1999) has also noted the salience for undocumented migrants of the theme of presence at stake in this slogan (p. 63). Coutin (2000) discusses this slogan in the particular case of (undocumented) Salvadoran asylum-seekers' struggles for legal recognition, insightfully likening it to the memorable passage in Dr. Seuss's children's classic Horton Hears a Who, where “in order to prevent the destruction of their world by those who doubted its existence, all of the Whos in Whoville had to shout, 'We are here! We are here!'” (p. 42). Under these circumstances, where Salvadorans were indeed seeking legal redress from the state, Coutin (2003) goes on to suggest that 'the assertion 'Aquí estamos' begins to seem more important than the defiant 'y no nos vamos'” (p. 186). In contrast to what I am depicting as the exuberant defiance of the 2006 mass mobilizations, Coutin (1999) explains: "By asserting their presence, these unauthorized immigrants claimed both legitimacy and formal membership in the polity” (p. $60)$.

6 It is not the proposition of this essay to discuss the intersections of migration, queer identities, and immigration politics. There is of course a robust and burgeoning field of excellent scholarship that does precisely that; see, e.g., Cantú (2009); Luibhéid (2002; 2008); Luibhéid and Cantú, eds. (2005); Puar (2007); Puar and Rai (2002); Somerville (2005). For another attempt to bring the insights of gender and sexuality studies to bear upon migration scholarship, more generally, see Andrijasevic (2009).

Notably, unknown to me upon first writing this essay, the activist campaign of undocumented students, generally raised and educated in the United States as the undocumented children of migrant parents, advocating for their own "legalization" through the DREAM Act (Development, Relief and Education for Alien Minors Act), inaugurated March 10, 2010 as "National Coming Out Day", and initiated a series of "coming out party" rallies throughout the United States, in which they openly declared themselves to be "undocumented but unafraid." The overtly LGBT/ queer theme of "coming out" (of "the closet") was tellingly coupled with the immigration discourse of "coming out of the shadows," and on one activist website, was accompanied with a quote from gay liberation icon, Harvey Milk; see: <www.dreamactivist.org/blog/2010/03/05/comeout/>; see also:

<www.nytimes.com/2010/03/12/us/politics/12immig.html?th\&emc=th>; for various activist sites within the broader campaign, more generally, see: <www.dreamact.com>; $<$ www.dreamactivist.org>; and <www.thedreamiscoming.com> (all sites accessed 30 June 2010).

7 For critical examinations of the equivocal and vexed figures of queer "nationhood" and "nationality," see Berlant and Freeman (1992) and Bérubé and Escoffier (1991); for a discussion of the problematic relation of this figure of queer nationhood to migrant “illegality” and undocumented migrant queers, see Fernández (1991). 


\section{Nicholas De Genova}

8 Indeed, queer politics is challenged as never before to subvert the neoliberal commodification of "queerness" itself as an identity, and furthermore, to stringently repudiate the precisely normalizing enlistment of a domesticated "queerness" into the service of neonationalist projects that aspire above all to "queer" migrants (especially Muslims, as "intolerant," inadequately "enlightened," insufficiently "modern" and "secular," and so forth).

9 I am very grateful to Ayça Çubukçu for calling this analogy to my attention.

${ }^{10}$ For key texts in the elaboration of an explicit critique of methodological nationalism, see Giddens (1973; 1985); Martins (1974); for a retrospective assessment and a critique of contemporary versions of these arguments, particularly those associated with the explicitly "cosmopolitan" work of Ulrich Beck (2000; 2002), as a new sociological "orthodoxy" on globalization, see Chernilo (2006; 2007); see also Beck and Sznaider (2006).

11 George W. Bush responded to a reporter's query with the remark, "I think the national anthem ought to be sung in English. And I think people who want to be a citizen of this country ought to learn English, and they ought to learn to sing the national anthem in English” (Montgomery, 2006). However, subsequent reporting disclosed that Bush himself may have participated in singing along with other Spanish-language versions of the anthem, and in any case, had apparently condoned their use, during his campaign overtures toward Latino electoral constituencies (Baker, 2006).

12 These reflections are indebted to theoretical insights and critical perspectives associated with scholars of the "autonomy of migration"; see, e.g., Mezzadra (2001, 2004, 2006, 2010); Mezzadra and Nielson (2003); Moulier Boutang (1998, 2001); Moulier Boutang and Garson (1984); cf. De Genova (2009; 2010b); Karakayali and Rigo (2010); Papadopoulos, Stephenson, and Tsianos (2008).

13 Notably, the slogan No Human Being Is Illegal (especially associated with anti-border movements in Europe, including the well-established German initiative Kein Mensch ist Illegal) is sometimes (as in Canada, for instance) more commonly enunciated as No One Is Illegal. As insightfully suggested by an anonymous reviewer of this essay, this latter formulation potentially introduces some additional ambiguity, such that the slogan has come to be deployed on behalf of "animal rights" and other concerns of deep ecology movements, dedicated to transcending a human-centric politics altogether.

14 For a related discussion, specifically regarding deportees' equivocal desire for the law, see Peutz (2007).

15 I am indebted to Ayça Çubukçu and Engin Isin for pushing me, in their respective and discrepant ways, to address this problem more fully. For a related critique of "human rights" in relation to the problem of sovereign power, see Çubukçu (2008).

16 Notably, beginning in October 2009, a wave of strikes by several thousand undocumented migrant workers demanding legal residence in France, articulated the themes of migrant presence and labour in remarkably similar terms; their principal slogan was: "On bosse ici, on vit ici, on reste ici” [We work here, we live here, we're staying here]. I am thankful to Sébastien Chauvin for bringing this analogy to my attention.

\section{References}

Agamben, G. (2005). State of exception (K. Attell, Trans.). Chicago, IL: University of Chicago Press.

Agnew, J. A. (1994). The territorial trap: The geographical assumptions of international relations theory. Review of International Political Economy, 1(1), 53-80.

Ahmad, M. I. (2002). Homeland insecurities: Racial violence the day after September 11. Social Text 72, 20(3), 101-115.

Ahmad, M. I. (2004). A rage shared by law: Post-September 11 racial violence as crimes of passion. California Law Review, 92(5), 1259-1330.

Almaguer, T. (1994). Racial fault lines: The historical origins of white supremacy in California. Berkeley, CA: University of California Press. 
Andrijasevic, R. (2009). Sex on the move: Gender, subjectivity, and differential inclusion. Subjectivity, 29, 389-406.

Baker, P. (2006, May 3). Administration is singing more than one tune on Spanish version of anthem. Washington Post. Retrieved from http://www.washingtonpost.com/wp-dyn/content/article/2006/05/02/AR2006050201594.html

Baker-Cristales, B. (2009). Mediated resistance: The construction of neoliberal citizenship in the immigrant rights movement. Latino Studies, 7(1), 60-82.

Bayoumi, M. (2008). How does it feel to be a problem? Being young and Arab in America. New York, NY: Penguin.

Beck, U. (2000). What is globalization? Cambridge, UK: Polity Press.

Beck, U. (2002). The cosmopolitan society and its enemies. Theory, Culture \& Society, 19(1-2), 17-44.

Beck, U., \& Sznaider, N. (2006). Unpacking Cosmopolitanism for the Social Sciences: A Research Agenda. British Journal of Sociology, 57(1), 1-23.

Berlant, L., \& Freeman, E. (1992). Queer nationality. boundary 2, 19(1), 149-180.

Bérubé, A., \& Escoffier, J. (1991). Queer/nation. Out/Look: National Lesbian and Gay Quarterly, 11, 1223.

Bloemraad, I., \& Trost, C. (2008). It’s a family affair: Intergenerational mobilization in the spring 2006 protests. American Behavioral Scientist 52(4) 507-532.

Brenner, N., Jessop, B., Jones, M., \& MacLeod, G. (2003). Introduction. In N. Brenner, B. Jessop, M. Jones, \& G. MacLeod (Eds.), State/space: A reader (pp. 1-16). Malden, MA: Blackwell.

Cainkar, L. (2002). No longer invisible: Arab and Muslim exclusion after September 11. Middle East Report 224. Retrieved from http://www.merip. org/mer/mer224/224_cainkar.html

Cainkar, L . (2003) Special registration: A fervor for Muslims. Journal of Islamic Law and Culture, 7(2), 73-101.

Cainkar, L. (2004). The impact of the September 11 attacks and their aftermath on Arab and Muslim communities in the United States. GSC Quarterly, 13. Retrieved from http:// www.ssrc.org/programs/gsc/publications/quarterly13/cainkar.pdf

Cainkar, L. (2005). Space and place in the metropolis: Arabs and Muslims seeking safety. City \& Society, 17(2), 181-209.

Cantú, L. (2009). The sexuality of migration: Border crossings and Mexican immigrant men. N. A. Naples \& S. Vidal-Ortiz, (Eds.). New York, NY: New York University Press.

Chacón, J. A., \& Davis, M. (2006). No one is illegal: Fighting racism and state violence on the U.S.Mexico border. Chicago, IL: Haymarket Books.

Chambers, S. A. (2009). A queer politics of the democratic miscount. borderlands e-journal, 8(2). Retrieved from http://www.border lands.net.au

Chernilo, D. (2006). Social theory's methodological nationalism: Myth and reality. European Journal of Social Theory, 9(1), 5-22.

Chernilo, D. (2007). A social theory of the nation-state: The political forms of modernity beyond methodological nationalism. New York, NY: Routledge.

Chock, P. P. (1991). "Illegal aliens" and "opportunity": Myth-making in congressional testimony. American Ethnologist, 18(2), 279-294.

Chon, M. \& Arzt, D. E. (2005). Walking while Muslim. Law and Contemporary Problems, 68, 215-54.

Chow, R. (2001). The secrets of ethnic abjection. In M. Morris \& B. de Bary (Eds.), "Race” panic and the memory of migration. (pp. 53-78). Aberdeen and Hong Kong: Hong Kong University Press.

Cole, D. (2003). Enemy aliens: Double standards and constitutional freedoms in the war on terrorism. New York, NY: The New Press.

Coutin, S. B. (1999). Citizenship and clandestinity among Salvadoran immigrants. PoLAR: Political and Legal Anthropology Review, 22(2), 53-63.

Coutin, S. B. (2000). Legalizing moves: Salvadoran immigrants'struggle for U.S. residency. Ann Arbor, MI: University of Michigan Press.

Coutin, S. B. (2003). Illegality, borderlands, and the space of nonexistence. In R. W. Perry \& B. Maurer (Eds.), Globalization under construction: Governmentality, law, and identity (pp. 171-202). Minneapolis, MN: University of Minnesota Press.

Crawford, C. (2007). “Aquí estamos y no nos vamos!”: Justice for janitors in Los Angeles and new citizenship claims. In D. Segura \& P. Zavella (Eds.), Women and migration in the U.S.-Mexico borderlands: A reader (pp. 306-324). Durham, NC: Duke University Press.

Çubukçu, A. (2008). Humanity must be defended? Unpublished Ph.D. dissertation, Department of Anthropology, Columbia University (New York). 


\section{Nicholas De Genova}

Daulatzai, S. (2007). Protect ya neck: Muslims and the carceral imagination in the age of Guantánamo. Souls, 9(2), 132-147.

De Genova, N. (1998). Race, space, and the reinvention of Latin America in Mexican Chicago. Latin American Perspectives, 25(5), 91-120.

De Genova, N. (2002). Migrant "illegality" and deportability in everyday life. Annual Review of Anthropology, 31, 419-47.

De Genova, N. (2005). Working the boundaries: Race, space, and 'illegality' in Mexican Chicago. Durham, NC: Duke University Press.

De Genova, N. (2007a). The production of culprits: From deportability to detainability in the aftermath of "Homeland Security." Citizenship Studies, 11( 5), 421-48.

De Genova, N. (2007b). The stakes of an anthropology of the United States (2007). CR: The New Centennial Review, 7(2), 231-77.

De Genova, N. (2008). “American” abjection: “Chicanos,” gangs, and Mexican/migrant transnationality in Chicago. Aztlán: A Journal of Chicano Studies, 33(2), 141-74.

De Genova, N. (2009). Conflicts of mobility, and the mobility of conflict: Rightlessness, presence, subjectivity, freedom. Subjectivity, 29, 445-466.

De Genova, N. (2010a). Alien Powers: Deportable Labour and the Spectacle of Security. In V. Squire, (Ed.), The contested politics of mobility: Borderzones and irregularity. London: Routledge.

De Genova, N. (2010b). The Deportation Regime: Sovereignty, Space, and the Freedom of Movement. Theoretical Overview in N. De Genova \& N. Peutz (Eds.), The deportation regime: Sovereignty, space, and the freedom of movement (pp. 33-65). Durham, NC: Duke University Press.

De Genova, N., \& Ramos-Zayas, A. Y. (2003). Latino crossings: Mexicans, Puerto Ricans, and the politics of race and citizenship. New York: Routledge.

Duggan, L. (1994). Queering the State. Social Text, 39, 1-14.

Fernandes, D. (2007). Targeted: Homeland security and the business of immigration. New York, NY: Seven Stories Press.

Fernández, C. (1991). Undocumented aliens in the queer nation. Out/Look: National Lesbian and Gay Quarterly, 11, 15-19.

Gamson, J. (1995). Must identity movements self-destruct? A queer dilemma. Social Problems, 42(3), 390-407.

Giddens, A. (1973). The class structure of the advanced societies. London: Hutchinson.

Giddens, A. (1985). The nation-state and violence. Cambridge, UK: Polity Press.

Gonzales, A. (2009). The 2006 mega marchas in Greater Los Angeles: Counter-hegemonic moment and the future of el migrante struggle. Latino Studies, 7(1), 30-59.

Gordon, J., \& Lenhardt, R. A. (2006). Citizenship talk: Bridging the gap between immigration and race perspectives. Fordham Law Review, 75, 2493-2520.

Halperin, D. M. (1995). Saint Foucault: Towards a gay hagiography. NewYork, NY: Oxford University Press.

Heiskanen, B. (2009, December 1). A day without immigrants. European Journal of American Studies, Special issue: 2009, document 3. Retrieved from http://ejas.revues.org/document7717.html

Hincapié, M. (2009). Aqui estamos y no nos vamos: Unintended consequences of current U.S. immigration law. In F. Ansley \& J. Shefner, (Eds.), Global connections, local receptions: new latino immigration to the southeastern United States (pp. 89-128). Knoxville, TN: University of Tennessee Press.

Hindess, B. (2000). Citizenship in the international management of populations. American Behavioral Scientist, 43(9), 1486-97.

Holloway, J. (1994). Global capital and the national state. Capital and Class, 52, 23-49.

Honig, B. (1998). Immigrant America? How foreignness “solves” democracy’s problems. Social Text, 56, 1-27.

Honig, B. (2001). Democracy and the foreigner. Princeton, NJ: Princeton University Press.

Human Rights Watch. (2002). Presumption of guilt: Human rights abuses of post-September 11 detainees. Retrieved from http:// www.hrw.org/reports/2002/us911

Johnson, K. R., \& Ong Hing, B. (2007). The immigrant rights marches of 2006 and the prospects for a new civil rights movement. Harvard Civil Rights -Civil Liberties Law Review, 42, 99-138.

Isin, E. F. (2008). Theorizing acts of citizenship. In E. F. Isin \& G. M. Nielsen (Eds.), Acts of Citizenship (pp. 15-43). London: Zed Books.

Isin, E. F. (2009). Citizenship in flux: The figure of the activist citizen. Subjectivity, 29, 367-388. 
Karakayali, S., \& Rigo, E. (2010) Mapping the European space of circulation. In N. De Genova \& N. Peutz, (Eds.), The deportation regime: Sovereignty, space, and the freedom of movement (pp. 123-144). Durham, NC: Duke University Press.

Kristeva, J. (1982). Powers of horror: An essay on abjection (Leon S. Roudiez, Trans.). New York, NY: Columbia University Press. (Original work published 1980)

Lazos Vargas, S.R. (2007). The immigrant rights marches (las marchas): Did the gigante (giant) wake up or does it still sleep tonight? Nevada Law Journal, 7,780-825.

Lipsitz, G. (2006). "Home is where the hatred is": Work, music, and the transnational economy. In A. Chabram-Dernersesian (Ed.), Chicana Cultural Studies Reader (pp. 299-313). New York, NY: Routledge.

Luibhéid, E. (2002). Entry denied: Controlling sexuality at the border. Minneapolis, MN: University of Minnesota Press.

Luibhéid, E. (2008). Sexuality, migration, and the shifting line between legal and illegal status. GLQ: A Journal of Lesbian and Gay Studies, 14(2-3), 289-315.

Luibhéid, E., \& Cantú, L. (Eds.). (2005). Queer migrations: Sexuality, U.S. citizenship, and border crossings. Minneapolis, MN: University of Minnesota Press.

Maira, S. (2004). Youth culture, citizenship and globalization: South Asian youth in the United States after September $11^{\text {th }}$. Comparative Studies of South Asia, Africa, and the Middle East, 24(1), 219-31.

Maira, S. (2009). Missing: Youth, citizenship, and empire after 9/11. Durham, NC: Duke University Press.

Maira, S. (2010). Radical deportation: Alien tales from Lodi and San Francisco. In N. De Genova \& N. Peutz, (Eds.), The deportation regime: Sovereignty, space, and the freedom of movement (pp. 295-325). Durham, NC: Duke University Press.

Martins, H. (1974). Time and theory in sociology. In J. Rex, (Ed.), Approaches to sociology (pp. 246-294. London: Routledge \& Kegan Paul.

Marx, K. (1976). Capital: A critique of political economy, Volume One. (Ben Fowkes, Trans.). New

York, NY: Penguin Books. (Original work published 1867)

McNevin, A. (2006). Political belonging in a neoliberal era: The struggle of the sans-papiers. Citizenship Studies 10(2): 135-51.

McNevin, A. (2009). Doing what citizens do: Migrant struggles at the edges of political belonging. LocalGlobal: Identity, Security, Community 6, 67-77.

Mezzadra, S. (2001). Diritto di fuga: Migrazioni, cittadinanza, globalizzazione. Verona, Italy: Ombre corte.

Mezzadra, S. (2004). The right to escape. Ephemera, 4(3): 267-275. Retrieved from http://www.ephemeraweb.org/journal/4-3/4-3mezzadra.pdf

Mezzadra, S. (2006). Citizen and subject: A postcolonial constitution for the European Union? Situations, 1(2), 31-42.

Mezzadra, S. (2010). Capitalism, migration, and social struggles: Towards a theory of the autonomy of migration. In Vicki Squire, (Ed.), The contested politics of mobility: Borderzones and irregularity. London: Routledge.

Mezzadra, S. \& Neilson, B. (2003). Né qui, né altrove-Migration, detention, desertion: A dialogue. borderlands e-journal, 2(1). Retrieved from http://www.borderlandsejournal.adelaide.edu.au/vol2no1_2003/mezzadra_neilson.html

Montgomery, D. (2006, April 28). An anthem's discordant notes: Spanish version of "Star-Spangled Banner" draws strong reactions. Washington Post. Retrieved from http://www.washingtonpost.com/wp-dyn/content/article/2006/04/27/AR2006042702505.html

Moulier Boutang, Y. (1998). De l'esclavage au salariat. Economie historique du salariat bridé. Paris: Presses Universitaires de France.

Moulier Boutang, Y. (2001). Between the hatred of all walls and the walls of hate: The minoritarian diagonal of mobility. In M. Morris \& B. de Bary (Eds.), "Race” panic and the memory of migration (pp. 105-30). Aberdeen and Hong Kong: Hong Kong University Press.

Moulier Boutang, Y., \& Garson, J-P. (1984). Major obstacles to control of irregular migrations: Prerequisites to policy. International Migration Review, 18(3), 579-592.

Nyers, P. (2003). Abject cosmopolitanism: The politics of protection in the anti-deportation movement. Third World Quarterly, 24(6), 1069-93. Reprinted in N. De Genova and N. Peutz, eds. The Deportation Regime: Sovereignty, Space, and the Freedom of Movement (pp. 413-41). Durham, NC: Duke University Press (2010).

Papadopoulos, D., Stephenson, N., \& Tsianos, V. (2008). Escape routes: Control and subversion in the $21^{\text {st }}$ Century. London: Pluto Press.

Peutz, N. (2007). Out-laws: Deportees, desire, and “the law.” International Migration, 455(3), 182-191. 


\section{Nicholas De Genova}

Phillips, C. (2009). Difference, disagreement and the thinking of queerness. borderlands e-journal, 8(2). Retrieved from http://www.border lands.net .au.

Puar, J. K. (2007) Terrorist assemblages: Homonationalism in queer times. Durham, NC: Duke University Press.

Puar, J. K., \& Rai, A. S. (2002). Monster, terrorist, fag: The war on terrorism and the production of docile patriots. Social Text 72, 20(3), 117-48.

Pulido, L. (2007). A day without immigrants: The racial and class politics of immigrant exclusion. Antipode, 39(1), 1-7.

Rancière, J. (1995). On the shores of politics (L. Heron, Trans.). New York, NY: Verso. (Original work published 1992)

Rancière, J. (1999). Dis-agreement: Politics and philosophy. Minneapolis, MN: University of Minnesota Press. (Original work published 1995)

Rancière, J. (2004). Who is the subject of the rights of man? South Atlantic Quarterly, 103(2/3), 297-310.

Rancière, J. (2006). Democracy, republic, representation. Constellations, 13(3), 297-307.

Robinson, W. I. (2006). “Aquí estamos y no nos vamos!” Global capital and immigrant rights. Race \& Class, 48( 2), 77-91.

Roediger, D. R. (1991). The wages of whiteness: Race and the making of the American working class. New York, NY: Verso.

Saito, N. T. (2001). Symbolism under siege: Japanese American redress and the "racing" of Arab Americans as “terrorists”. Asian Law Journal, 8, 1-29.

Schinkel, W. (2010, January). Culturalism and the sociology of "integration.” Paper presented at the conference "The language of difference: Mechanisms of inclusion and exclusion of migrants, 19452005," sponsored by the Department of History, University of Leiden, Netherlands.

Somerville, S. B. (2002). Introduction: Queer fictions of race. MFS: Modern Fiction Studies, 48(4), 787794.

Somerville, S. B. (2005). Sexual aliens and the racialized state: A queer reading of the 1952 U.S. Immigration and Nationality Act. In E. Luibhéid \& L. Cantú (Eds.), Queer migrations: Sexuality, U.S. citizenship, and border crossings (pp. 75-90). Minneapolis: University of Minnesota Press.

Stoler, A. L. (2006). On degrees of imperial sovereignty. Public Culture 18(1): 125-146.

Takaki, R. (1979). Iron cages: Race and culture in $19^{\text {th }}$-century America. New York, NY: Oxford University Press.

Varsanyi, M. W. (2006). Interrogating “urban citizenship” vis-à-vis undocumented migration. Citizenship Studies 10(2): 229-249.

Villa, R. H. (2000). Barrio-logos: Space and place in urban Chicano literature and culture. Austin, TX: University of Texas Press.

Volpp, L. (2002). The citizen and the terrorist. UCLA Law Review, 49, 1575-1598.

Wimmer, A., \& Glick Schiller, N. (2003). Methodological nationalism, the social sciences, and the study of migration: An essay in historical epistemology. International Migration Review, 37(3), 576-610. 